\title{
Vendor Oversight Document
}

National Cancer Institute

\section{Source}

National Cancer Institute. Vendor Oversight Document. NCI Thesaurus. Code C115744.

Records describing the monitoring and supervising work conducted by a vendor. 